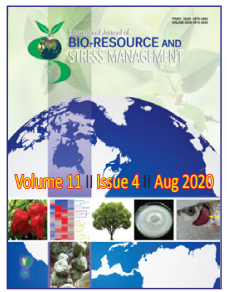

\title{
Homegarden Agroforestry in Ethiopia- A Review
}

\author{
Biruk Kefale
}

\author{
Natural resource department, Mizan ATVET College, Ethiopia
}

Corresponding Author
Biruk Kefale
e-mail: birukkefale51@gmail.com
Citation: Kefale, 2020. Home garden Agroforestry
in Ethiopia-A Review. International Journal of Bio-
resource and Stress Management 2020, 11(4), 345-
352. HTTPS://DOI.ORG/10.23910/1.2020.2118d.

Copyright: (c) 2020 Kefale. This is an open access article that permits unrestricted use, distribution and reproduction in any medium after the author(s) and source are credited.

Data Availability Statement: Legal restrictions are imposed on the public sharing of raw data. However, authors have full right to transfer or share the data in raw form upon request subject to either meeting the conditions of the original consents and the original research study. Further, access of data needs to meet whether the user complies with the ethical and legal obligations as data controllers to allow for secondary use of the data outside of the original study.

Conflict of interests: The authors have declared that no conflict of interest exists.

\begin{abstract}
Agroforestry is an ancient practice and also the farmers are too much familiarized with it in Ethiopia. All homegardens contain some sort of food crops and many trees produce fruits or other forms of food which shows that the most important function of homegardens is food production. Home garden is an integrated system that comprises different things in its small area. Home gardens have been identified as the oldest land use activity. In general terms, all homegardens consist of three main layers; of these herbaceous layers near the ground, a tree layer at upper levels, and intermediate layers in between. The compositions of crops grown in homegardens can be grouped based on function as ornamental, fruits, food crops, vegetables, medicinal, spices and fodder, building materials and fuel woods. Traditional socio-cultural and ecological knowledge often permits the farmer to decide the species choice and the spatial and time sequence for growing these species. Homegardens are perceived to be highly sustainable in both biophysical and socioeconomic terms. Homegardensmay be characterized by diverse composition, complexstructure and multiple functions. Homegardens are realized as an important self-sustaining agroecosystem with the dual function of production and on farm conservation of the agrobiodiversity.The perceived threat of genetic erosion to plant resources for food and agriculture could be arrested by ensuring the worth of homegardens, because they ensure conservation of useful plants through continued use. Ethiopian homegardens are unique in their architecture, crop mix and the key (dominant) species.
\end{abstract}

Keywords: Agroforestry, home garden, compositions

\section{Introduction}

Home garden agroforestry practice can be defined as a landuse system, which involving deliberate management of multipurpose trees and shrubs in intimate association withannual and perennial agricultural crops and invariably livestock within the compounds of individual houses, the whole tree-crop-animal unit being intensively managed by family labor (Kumar and Nair, 2004). A home garden is an integrated system that comprises different things in its small area that produces a variety of foods and agricultural products including staple crops, vegetables, fruits, medicinal plants and so on (Agbogidi and Adolor, 2013). Homegardens have been identified as the oldest land use activity (Pushpaku et al., 2012). Homegardens are vivid examples of production systems with rich diversity that serves both development and conservation functions (Hailu and Asfaw, 2011).

The household garden is a small-scale production system supplying
Article History

RECEIVED in $10^{\text {th }}$ June 2020 RECEIVED in revised form $07^{\text {th }}$ July 2020 ACCEPTED in final form $07^{\text {th }}$ August 2020 
plant and animal consumption and utilitarian items either not obtainable, affordable, or readily available through retail markets, field cultivation, hunting, gathering, fishing, and wage earning. Household gardens tend to be located close to dwelling for security, convenience, and special care. They occupy land marginal to field production and labor marginal to major household economic activities. Featuring ecologically adapted and complementary species, household gardens are marked by low capital input and simple technology (Galhena et al., 2013).

Agroforestry is an ancient practice and also the farmers are too much familiarized with it in Ethiopia. Agroforestry system is the basic extension package in Ethiopia. It contributes incredible benefits via socio-economic and environment (Endale, 2019). Home gardens are found in both rural and urban areas in predominantly small-scale subsistence agricultural systems (Nair, 1993)

Due to tree-based agroforestry practice, homegarden, is more profitable than mono-cropping (Linger, 2014) Due to its fact and incredible benefits through economic, social and environmental, almost all of smallholder farmers are more familiarly with agroforestry system or agroforestry practice in Ethiopia(Muleta et al., 2007, Abebe et al., 2010, Kebebew and Urgessa, 2011).

According to Wolaita and Gurage (Zemede and Zerihun, 1997), Arbaminch area (Wassihun et al., 2003), Sidama (Tesfaye, 2005) and Wolaita (Talemos Seta, 2007), reports traditional homegardens of Ethiopia demonstrate a sustainable agricultural practice that is environmentally friendly and allows the harvesting of diverse products in response to the needs of farming families and urban dwellers.

\section{Definition of Homegarden}

Homegardenis locally known as yeguaro-ersha, Yeguaro Masa, Yeguarolrsha, and Yeatikilt Bota (in Amharic language), eddo, Hoddo, Boro, Mandubee in Afan Oromo (in oromo language) (Zemede, 2001a, Regassa, 2011) and dhri-bet (in tigregna language) (Gebremedhin and Mulubrhan, 2007). The former term literally means the backyard farm while at the same time indicating the closeness of the cultivation plot to the house (Zemede, 2001a).In other areas there are many such names includes Daddegoyo in Keficho DaniioGade in Gado (Wassihun et al., 2003), GatteOuduma in Gedeo (Tamrat, 2010).

According (Galhena et al., 2013), home garden agroforestry deals with the cultivation of multipurpose and multi-storied trees and crops combined with animal husbandry around a homestead.Homegarden is described as an agroforestry practice that combines physical, social and economic functions on the area of land around the family home (Udofia et al., 2012). Homegarden is a traditional land-use system which extensively practiced throughout the world (Wajtkowski, 1998). Homegardens are one of the most complex and diverse agro ecosystems worldwide and played an important role towards the development of early agriculture and domestication of crops and fruit trees, a still ongoing process (Abdoellah et al., 2006).

\section{Types of Homegardens}

Homegardens worldwide are integrated into family life and may be divided broadly into traditional gardens, resulting from a long history of adaptation of plants to local needs and conditions, and model gardens, often developed with external support, ideas and imported technologies. In urban areas and isolated rural areas, a traditional kitchen garden may be inexpensively established - a small plot from which vegetables and garnishes are taken each day to improve meals. It can be watered with the waste water from dish washing and bathing. Depending on local environmental sensitivity and available recycling technologies such as composting and biogas production, nutrients can be utilized from kitchen and human wastes. Requiring a little more space and capital invested, traditional mixed gardens integrating poultry, other livestock and fish ponds provide productive opportunities for waste transformation and nutrient recycling. Agroforestry gardens maximize use of scarce land by cultivating crops in multiple layers:-trees, vines, and under storey and root crops (FAO, 2004).

According to (Shrestha et al., 2001), fenced area around house, is the most common type of homegarden in Nepal. These homegardens are maintained around the homestead and are generally fenced to keep livestock away from the area. In Ethiopia, the homegarden area, which has variable shapes and sizes, includes the living house, animal houses, grain stores, drying places, and plots of garden species. It is usually fenced and the fence is frequently reinforced by multipurpose live tree and shrub species. According to (Zemede, 2001b) report the common garden sizes range from about $500 \mathrm{~m}^{2}$ to more than 2,500 $\mathrm{m}^{2}$ (a quarter of a hectare), but in extreme cases, gardens as small as $20 \mathrm{~m}^{2}$ and as large as $10,000 \mathrm{~m}^{2}$ have been recorded. Larger gardens, approaching the upper limit, are more frequent in households where the homegarden is the only cultivated land available. When crop composition is considered, the gardens are typically of the mixed type (Zemede, 2001b).

Common locations for gardens in Ethiopia, in relation to the house are back yards, front yards, side yards and those that almost encircle the house. In many rural villages where homegardening is well developed, the space in front of the house is with a clean green meadow as a family resting and socializing place. In some areas, fences confine gardens while in others they merge with crop fields and may be fenced together (Zemede, 2001b).

\section{Structure and Composition of Homegardens}

Almost all homegardens have the most visible characteristics such as layered canopy and harmonious admixture of species (Soemarwoto et al., 1985, Fernandes and Nair, 1990) and 
specific place and functions but the main difference is seen in homegarden size, shape, intensity of cultivation, the types of crops grown and complexity of species diversity (Brownrigg, 1985, Christanty, 1985, Okigbo, 1990). In general terms, all homegardens consist of three main layers (Nair, 1993); of these herbaceous layers near the ground, a tree layer at upper levels, and intermediate layers in between. The lower layer can usually be partitioned into two, with the lower most (less than $1 \mathrm{~m}$ height) dominated by different vegetable and medicinal plants, and the second layer (1-3 $\mathrm{m}$ height) being composed of food plants such as cassava, banana, yam, and so on (Fernandes and Nair, 1986, Nair, 1993, Ninez, 1987).

The compositions of crops grown in homegardens can be grouped based on function as ornamental, fruits, food crops, vegetables, medicinal, spices and fodder, building materials and fuel woods (Kumar and Nair, 2004). The patterns and compositions of homegardens are disordered due to the educational level of gardener, the indigenous knowledge of farmer, the market and the size of land availability. Thus, several patterns of homegarden have no particular patterns (Brownrigg, 1985, Zemede, 2001b) and also sociocultural, environmental and ecological factors determine species composition and types of homegardens (Fernandes and Nair, 1986). Plant compositions in Ethiopian homegardens are grouped under the three main types of garden crops, live fence species, useful wild and semi-wild plants (Zemede, 2001b).

Homegardens in Ethiopia have variable shapes: some almost encircle the house others square, rectangle or irregular (Zemede, 2001b, Zemede and Zerihun, 1997). Patterning of the crop also varies from place to place. For instance, the plants like bamboos are on the outer margins, some are planted in side margin next to the fence, chat, coffee and enset are planted in the depressions of rows, others like perennial planted far apart with water collection depressions (Zemede and Zerihun, 1997, Tesfaye, 2005). Gardens usually have boundaries from home of other homegardens by fences; dry woody material, stones, and live plants (thorny shrubs) and sometime bounded by natural barriers like rivers, gorges (Zemede and Zerihun, 1997).

\section{Indigenous Knowledge}

Farmers manage the trees inside the home garden to reduce light competition by means of pruning. Farmers use the excrement of cattle and humans to keep the garden fertile and productive while they maintain sanitation (Hailu and Asfaw, 2011). In the tropical and sub-tropical countries many farmers have traditional knowledge and practices for conserving agricultural ecosystems and a means of integrating land use systems (Abebe and Bongers, 2012).

Cordiaafricana, Erythrinabrucei and Millettiaferruginea are species that the farmers preferred to promote fertile soil. $98 \%$ of respondents produced plants with different use values mainly for home consumption to be harvested whenever they needed to use throughout the year. The prominent species that occurred in the SNNP region home gardens was Enseteventricosum, which provided food at a steady rate as an appropriate management system (Bishaw and Abdelkadir, 2003).

In Southern Ethiopia, women were the only labour processing and preparing food from the plants which were dominant in the home garden, namely enset, while men performed, other harder work. This indicated that women were the only persons processing this food which could be eaten when food shortages occurred. The food takes a long time to prepare and requires care and experience or indigenous knowledge.

\section{Species Diversity}

According to Reta (2016). In Hawassa city Ethiopia, 258 useful plant species were observed and identified belonging to 186 genera and 76 families, including $14(5.43 \%)$ vegetable plant species, $23(8.92 \%)$ fruit plant species, $15(5.81 \%)$ spices plant species, $12(4.65 \%)$ root and tubers plant species, $8(3.1 \%)$ cereals, pulses and oil seeds plant species, $3(1.16 \%)$ stimulant plant species, $12(4.65 \%)$ fragrant plant species, $122(47.29 \%)$ ornamental plant species, 39(15.12\%) firewood plant species, $4(1.55 \%)$ animal feed plant species and $41(15.89 \%)$ medicinal plant species. From those Fabaceae was the highest families number of species followed by Euphorbiaceae and Asteraceae and the highest genera were Euphorbia (8 species) followed by Astera (7 species).

In Bishoftu town of Oromia, The homegarden plant composition gave 115 species belonging to 94 genera and 51 families that were identified and classified into 15 functional groups. Among them, 50, 37, 21 and 7 plants were herbs, trees, shrub and climbers, respectively. Further analysis indicated that 75 and $25 \%$ were cultivated and wild; 95.7 and $4.3 \%$ were non-endemic and endemic species. Rutachalenpensis that was found in all the 30 homegardens $(100 \%)$ was the most frequent species followed by Rosmarinus officinalis (83.33\%) (Regassa, 2014). Tefera et al. (2016) records that 52 (trees 63\%, shrubs 12\%, herbs $19 \%$ and climbers $9 \%$ ) species belonging to 35 genera and 25 plant families in dilla district. He also report that in Qollaagroecological zone is coffee-fruit crops- tree due to:- moist and warm climate, the practices of planting different multipurpose trees which are used as coffee shade and fruit trees are very common ; In Woynadegaand degaagroecolgy mainly Enset-CoffeeTreeand enset-tree system was practicedbecause, Enset provide source of food, coffee for income /cash/, boyena and godere supplement the household food consumption and also it has economical, cultural and environmental benefits.

Tefera and Kim (2019), recorded the 70 (42 woody and 28 herbaceous) total number of plants species wich is comparable with a study done in dilla district 75 different plant species with trees (44\%), shrubs (20\%), herbs (32\%) and climbers (4\%) were recorded under ten use 
categories. Jabithenan district in Northern part of Ethiopia, a total of 69 plant species also recorded and identified by Tefera et al. (2016), also reported 52 plant species in three agroecological Zones of DillaZuria District. The study identified 39 families comprising of 68 angiosperm and 2 gymnosperms. Fabaceae was the dominant family with 10 species followed by Euphorbiaceae, Myrtaceae, Poaceae, Lamiaceae and Solanaceae each 4 species while others Alliaceae, Asteraceae, Boraginaceae, Musaceae, Rubiacea, Rutaceae and Zingiberaceae with two species.

\section{Importance of Homegarden Species}

\subsection{Food plants}

Food production is the primary role of most, if not all, of the homegardens (Nair, 1993). Hence, the variety of annual andperennial crops and vegetables grown in these gardens provide a secure supply of fresh produce throughout the year (Shrestha et al., 2001). Homegardens may become the principal source of household food and income during period

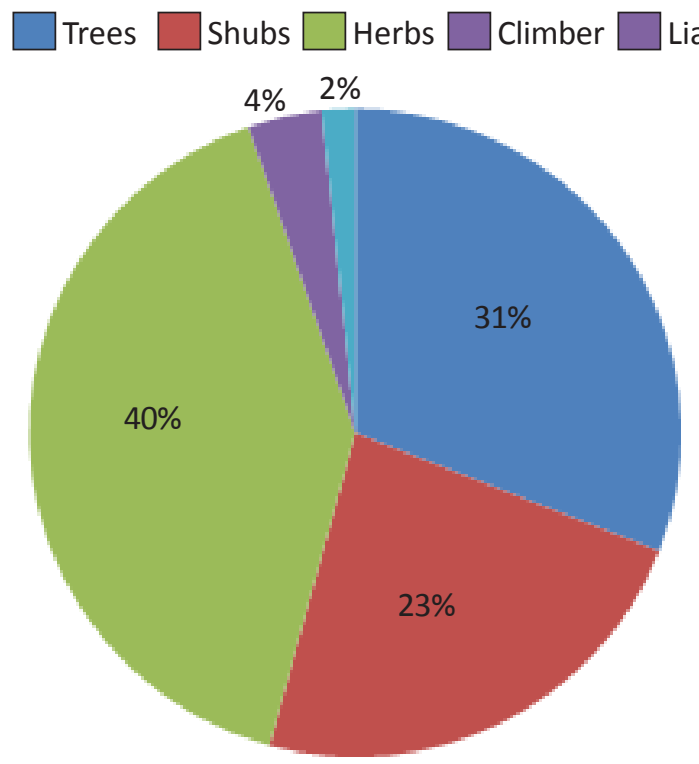

Chart 1: useful plant species diversity in different ethiopia homegardens districts

of stress, as in Kampala, Uganda after the civil war, where urban agriculture is reported to have subsistantially fed the city (Marsh, 1998). In Java, an owner of homegardens have something available to harvest throughout the year, either for consumption, or for sale and this availability is specifically important to the economic stability of poor households, particularly during the period between rice harvests (Soemarwoto, 1987).

In different research, farmers identified and familiarized themselves with their preferred species which were used for food and other purposes.(Mengistu and Asfaw, 2016) showed that, on average, 59 species were familiar to farmers; 25 species were preferred for the purpose of food, 21 species for medicine, sale, live fencing, building or home materials, shade and ornamental use, and 38 species for fuel purposes. Home gardens in the area produced a significant amount of the food needed by the family in addition to minor and supplementary products. Of the 60 households interviewed, 59 plant species were listed as most important food crops by the local people (Mekonen et al., 2015).

All homegardens contain some sort of food crops and many trees produce fruits or other forms of food. This shows that the most important function of homegardens is food production (Fernandes and Nair, 1986). According to (Zemede, 2001b), about $74 \%$ of the crops documented in homegardens were categorized as food crops while the remaining $26 \%$ were non-food crops, showing the importance of homegardens in supplying food to the household. In addition, out of 112 species of crops found growing in southern and southwestern Ethiopia, 69 (62\%) were recorded in homegardens only, 26 (23\%) both in homegardens and crop fields and 17 (15\%) in fields only. In most parts, about $85 \%$ of the cultivated species are encountered under cultivation in homegardens, about $50 \%$ always in home gardens and about 35\% in homegardens and fields. Examples of crops that are found in Ethiopian homegardens include the juicy (saccharine) sorghum, popping sorghum, fast maturing and sweet types of maize, robust, thick-stemmed and large and thick leaved Brassica carinata, the perennial Capsicum annuum and climbing types of Phaseolus and other legumes (Zemede, 2001b).

Among homegarden species $36.52 \%$ are identified for food and nutrition sources in bishoftu town. The majority of these food and nutrition plants were fruits and vegetable that are cultivated throughout the year and directly used for household family food and nutrition sources on daily basis (Regassa, 2014) and in hawassa town (27.91\%) species of the total useful plant flora of Hawassa city home garden. With the majority of fruits, spices, vegetables, root and tuber crops, cereals, pulses and oils which are belonging to the Dioscoriaceae,Lamiaceae and Rutaceae families (Reta, 2016). About $44 \%$ vegetables followed by $27 \%$ fruit treeswere reported by TsegazeabeHadushfrom those the majority of edible fruitslike papaya, guava, mango, avocado, orange, citron, mostly used as food source in Hiwane, HintaloWejerat of Tigray, Northern Ethiopia (Tsegazeabe and Teferi, 2012).

Yem districtenset-dependent people, the life and culture of Yem is very much tied with ensetfarming in a similar manner to that of Sidama and Gedeo people.

Generally, from 13 homegarden of different Ethiopia districts are summarized as follow (graph 1). Which shows that in hawasa district the highest homegarden plant species are recorded followed by sebeta,bishoftu and yem districts. But the smallest homegarden plant species are recorded in chiro followed by bulen districts. This difference may from agroecology,sample size of the researcher,land use system,knowledge of the local people concerning homegarden 
agroforestry.

\subsection{Ornamental plants}

The ornamental plant use category consisted of 122 species from which 18 (14.75\%) are native to Ethiopia, 104 (85.25\%) is exotic.

In Hawassa city Ornamental plants are found in more than $87 \%$ of home gardens. The most frequently distributed ornamental plants are Melia azedarch, Jacaranda mimosifolia, Cupressus lusitanica, Callistemon citrinus, Hibiscus rosa-sinensis, Senna spectabilis, Duranta repens, Duranta erecta, Bougainnville aglabra, Nerium olander, Terminalia mentalis, Araucaria

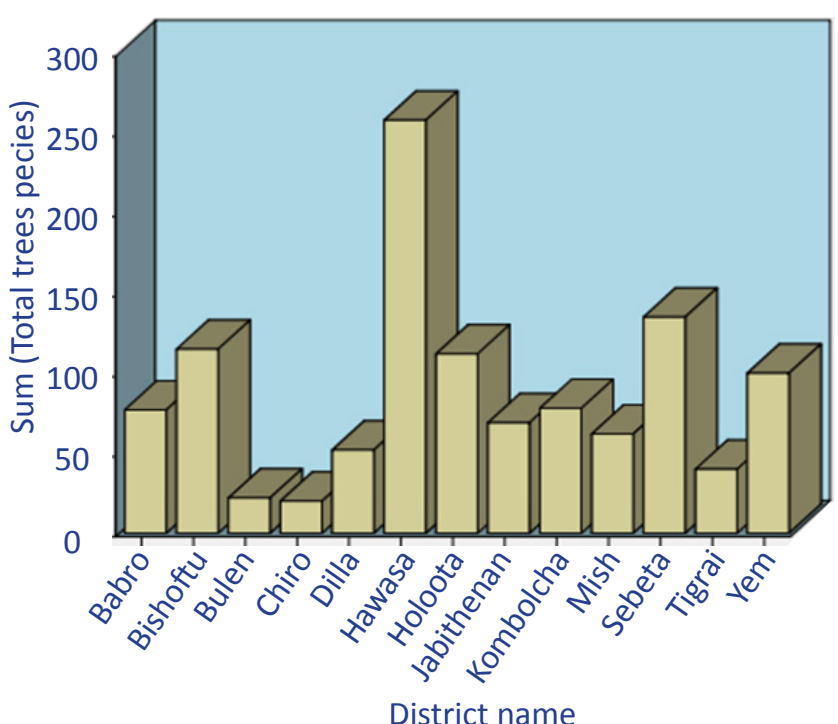

Graph:1 Tree species diversity of different districts of Ethiopia

heterophylla, Thevetia peruviana, Cupressus lusitanica and Ficus benjamina.

\subsection{Fodder plant species}

Next to food, firewood is the scarcest item in developing countries. More than one third of the world is dependent upon firewood to supply their energy needs and ninety percent of the people in the poorest countries depend upon it as their chief source of fuel. Tree products, such as timber products, charcoal, firewood, and fodder constitute important safety nets and are part of income diversification strategies for many communities in developing countries facing increased climate variability and climate hazard risks (Hines and Eckman, 1993).

Some of the highly preferred species identified for building materials include: Acacia mellifera, Dichrostachys cinerea, Bridelia micrantha, Dalbergia arbutifolia, Prunus africana, and Olea capensis (Hines and Eckman, 1993).

\subsection{Medicinal plants}

Dwellers and traditional healers believe that growing medicinal plants in homegarden is having a doctor at home (Regassa, 2014), because medicinal plants from homegardens are used for number of human health disorders and animal diseases treatments and also closer to houses for ease of access for the human health benefits. Many herbs are planted for their medicinal as well as food value while some of the species of homegarden crops are primarily cultivated for their medicinal use (Zemede, 2001b). It is further noted that while the main garden crops within the same agroecological region are generally common, those cultivated as traditional medicinal plants vary considerably from household to household.

As Kebede, 2010 report shows out of 59 species, 21 (35.59\%) species for medicine purposes. Reta (2016), record in hawasa district $41(15.89 \%)$ medicinal plant species were recorded in home garden. Assamere and Asmamaw (2019) reported that Hageniaabyssinicawas used to treat stomach ache.

\subsection{For socio-cultural role}

Homegardens have important social and cultural functions (Christanty, 1990). For instantce, the front part of a homegarden is not planted being kept clean. This is an important place for socializing, where children learn cultural and social values from their elders, where religious rituals and cultural ceremonies take place (Kumar and Nair, 2004). Many products of homegardens also have a social function, since neighbors can freely obtain certain fruits, leaves or tubers for religious or medicinal purposes from each other. Some plant species in homegardens are believed to have a magical value others are necessary for religious ceremonies, e.g., Hindu Balinese families need their homegardens as source and place for making sacrifices (Soemarwoto, 1987).

\subsection{Women participation in homegarden}

Agriculture is the main activity of men in the country. However, women play their own role in the management of home gardens and also of the farm fields. For example carrying animal manure to the farm lands, soil preparation, weeding and harvesting are some of the activities in which women had direct involvement in different districts (Galhena et al., 2013; Gebrehiwot, 2018). This work division between males and females was one way that farmers managed their human resources for activities like crop selection.

In the home garden, women are frequently engaged in cultivation, while men need to farm the land used for cash crop production. Women play great role in the management of home gardens species and also of the farm fields. According to Chayal et al. (2013) women formed about $43 \%$ of the agricultural labor force globally and in developing countries.

As research on home garden conducted shows in the Sidama district that women's access to land, markets, trading and the decision-making process had been restricted institutionally at the household and community levels. Because the majority of farm women were illiterate and little know-how about the techniques of farming due to several cultural taboos (Chayal et al., 2013). But Proclamation, (No.456/2005) FDRE says that "Women, who want to engage in agriculture, shall have the 
right to get and use rural land" FDRE, (2005).

\subsection{Sustainability of homegarden systems}

Homegardens are perceived to be highly sustainable in both biophysical and socioeconomic terms. Because of the lack of widely acceptable sustainability criteria, however, these perceptions are not quantifiable. The following section evaluates the situation based on generally 'accepted' notions of sustainability Kumar and Nair (2004).

\section{Biophysical Aspects}

\subsection{Nutrient cycling}

It is generally regarded that the homegardens possess a closed nutrient cycling, much similar to the tropical forests (Nairm et al., 1999). The dynamics of litter production and decomposition and subsequent bioelement release, which endow sustainability to these forests (Lavelle et al., 1995), are, therefore, relevant to homegardens. Biological N2 fixation and mycorrhizalassociations are important; yet, little quantitative information seems to exist in this respect. In particular, behavior of N2-fixing trees that are abundant in these systems, information on the quantities of $\mathrm{N}_{2}$ fixed, and its further utilization by associated crops are not well documented. Nutrients in tree biomass are returned to soil either naturally through litterfall and root turnover, or deliberately through pruning.

Despite their importance in maintaining organic matter and nutrient flows, studies on litter and fine root dynamics in the homegarden system are few and uncoordinated. Moreover, sometimes homegarden litter is removed for fuel and/or as organic manure (to be used elsewhere), on which again, little quantitative data exist.

\section{Conclusion}

Homegardenis used for social and economic developments and environmental regulation. It encompasses a wide range of agrobiodiversity serving the garden owners in particular and community in general in various livelihood development functions which include food and feed, spices and condiments, stimulants, socio-cultural and health benefits, environmental regulation, and provision of construction materials, fuel and detergents.Most community have good understandings of both existence of climate change indicators in their locality and what led those indicators to occur.

\section{References}

Abebe, T., Wiersum, K., Bongers, F., 2010. Spatial and temporal variation in crop diversity in agroforestry homegardens of southern Ethiopia. Agroforestry systems 78, 309-322.

Abdoellah, O.S., Takeuchi, H.H.Y., Satoru, K., Okubo, S., Parikesit, 2006. Commercialization of homegardens in an Indonesian village: vegetation composition and functional changes. Agroforestry Systems 68, 1-13.
Agbogidi, O.M., Adolor, E.B., 2013. Home gardens in the maintenance of biological diversity. Department of Botany, Faculty of Science, Delta State University, Abraka, Delta State, Nigeria.

Assamere, A.H., Asmamaw, M.B., 2019. Homegarden plants in Legambo District (Chiro Kebele) South Wollo, Ethiopia: Future implication for food security and rehabilitation program. African Journal of Plant Science 13(9), 246-254.

Abebe, T., Bongers, F., 2012. Land-use dynamics in enset-based agroforestry homegardens in Ethiopia. In Forest-people interfaces 2012. Wageningen Academic Publishers, Wageningen, 69-85.

Bishaw, B., Abdelkadir, A., 2003. Agroforestry and community forestry for rehabilitation of degraded watersheds on the Ethiopian highlands. International Conference on African Development Archives, Paper 78.

Brownrigg, L., 1985. Homegardening in International Development. Education, Washington, 32-41.

Christanty, L., 1985. Homegardens in tropical asia, with special reference to Indonesia. In: International workshop on tropical homegardens. Institute of Ecology, Padjadjaram University, BandungIndonesia, December 2-9, 39-42.

Chayal, K., Dhaka, B.L., Poonia, M.K., Tyagi, S.V.S., Verma S.R., 2013. Involvement of farm women in decision-making in agriculture. Studies on Home and Community Science 7(1), 35-37.

Christanty, L., 1990. Homegardens in tropical Asia with special reference to Indonesia. In: Landauer, K., Brazil, M. (Eds), Tropical Homegardens. United Nations University Press, Tokyo, 9-20.

Endale, B., 2019. Review on agro-forestry system and its contribution in Ethiopia. International Journal of Sustainability Management and Information Technologies 5, 8-14.

FAO, 2004. Livelihoods grow in gardens: Diversifying rural incomes through home gardens, Diversification booklet 2, Rome.

Fernandes, E.C.M., Nair, P.K.R., 1986. An Evolution of the structure and function of tropical homegardens. Agricultural Systems 21, 279-310.

Fernandes, E.C.M., Nair, P.K.R., 1990. An Evaluation of the Structure and function of Tropical Home Gardens. In: Tropical Homegardens, 105-114 (Landauer, K., Brazil, M. (Eds.), United Nations University Press, Tokyo.

Galhena, D.H., Freed, R., Maredia, K.M., 2013. Home gardens: a promising approach to enhance household food security and wellbeing. Agriculture \& Food Security 2, 8.

Gebremedhin, T., Mulubrhan, H., 2007. Women in backyards: Root crop production and biodiversity management in backyards: A Case study in five selected woredas of tigray regional State, Northern Ethiopia DCG Report No, 50.

Gebrehiwot, K.A., 2018. A review on waterlogging, salinization and drainage in Ethiopian irrigated agriculture. Sustainable Water Resources Management 4(1), 55-62. 
Hailu, H., Asfaw, Z., 2011. Homegardens and agrobiodiversity conservation in sabata town, Oromia regional state, Ethiopia. SINET: Ethiopian Journal of Science, 34, 1-16.

Hines, D.A., Eckman, K., 1993. Indigenous multipurpose trees of Tanzania: uses and economic benefits for people.

Kumar, B.M., Nair, P.K.R., 2004. The enigma of tropical homegardens. Agroforestry Systems, 61, 135-152.

Kebebew, Z., Urgessa, K., 2011. Agroforestry perspective in land use pattern and farmers coping strategy: Experience from southwestern Ethiopia. World Journal of Agricultural Sciences 7, 73-77.

Linger, E., 2014. Agro-ecosystem and socio-economic role of homegarden agroforestry in Jabithenan District, North-Western Ethiopia: implication for climate change adaptation. Springer Plus, 3, 154.

Lavelle, P., Lattaud, C., Trigo, D., Barois, I., 1995. Mutualism and biodiversity in soils. In The significance and regulation of soil biodiversity. Springer, Dordrecht, 23-33.

Marsh, R., 1998. Building on traditional gardening to improve household food security. Food nutrition and agriculture, 4-14.

Mengistu, B., Asfaw, Z., 2016. Woody species diversity and structure of agroforestry and adjacent land uses in Dallo Mena District, South-East Ethiopia. Natural Resources 7(10), 515.

Mekonen, T., Giday, M., Kelbessa, E., 2015. Ethnobotanical study of homegarden plants in Sebeta-Awas district of the Oromia Region of Ethiopia to assess use, species diversity and management practices. Journal of Ethnobiology and Ethnomedicine 11, 64.

Muleta, D., Assefa, F., Nemomissa, S., Granhall, U., 2007. Composition of coffee shade tree species and density of indigenous arbuscular mycorrhizal fungi (AMF) spores in Bonga natural coffee forest, southwestern Ethiopia. Forest Ecology and Management 241, (1-3), 145-154.

Nairm, M.T., Guerrerom, L., Arenasm, O.L., Nair, P.K., 1999. Chemically deposited copper oxide thin films: structural, optical and electrical characteristics. Applied Surface Science 150(1-4), 143-151.

Nair, P.K.R., 1993. An introduction to agroforestery. Kluwer Academic Publisher London.

Ninez, V., 1987. Household Gardens: Theoretical and Policy Considerations. In: Agricultural Systems, 23, 167-186.

Okigbo, N.B., 1990. Homegardens in tropical Africa. In: Landauer, K.,Brazil, M. (Eds.), Tropical Homegardens, United Nation University Press, Tokyo, 21-40.

Pushpaku M.D.K.N.G., Silva, B.M., G.L.L.P., Weerahewa, J., Punyawardwardena, B.V.R., 2012. A review of research on homegardens in Sri lanka: the status, importance and future perspective. Tropical Agriculturist, 160, 55-125.

Regassa, B., 2011. Agrobiodiversity in the homegardens of Bishoftu Town, Oromia National Regional State, Ethiopia.

Reta, R., 2016. Useful plant species diversity in homegardens and its contribution to household food security in
Hawassa city, Ethiopia. African Journal of Plant Science 10(10), 211-233.

Shrestha, P., Gautam, R., Rana, R.B., Sthapit, B., 2001. Homegardens in Nepal: status and scope for research and development. In: Watson J.W., Eyzaguirre, P.B. (Eds.), Homegardens and in-situ conservation of Plant Genetic Resources in Farming Systems. Proceedings of the Second International Home Gardens Workshop, 17-19 July 2001, Witzenhausen, Federal Republic of Germany, 105-124.

Soemarwoto, O., Soemarwoto, I., Karyono, 1985. The Javanese homegardens as an integrated agroecosystem. Foods and Nutrition Bulletin 7(3), 87.

Soemarwoto, O., 1987. Homegardens: A Traditional Agroforestry System with a Promising Future. In: Steppler, H., Nair, P.K.R. (Eds.), Agroforestry: A Decade of Development. International Council for Research in Agroforestry, Nairobi, 157-170.

Tesfaye, A., 2005. Diversity in Homegarden Agroforestry Systems of Southern Ethiopia. Ph.D. dissertation, Wageningen University, Netherlands, 143.

Tsegazeabe, T.H., Teferi, M., 2012. Agroforestry practices and flora composition in backyards in Hiwane, Hintalo Wejerat of Tigray, Northern Ethiopia. International Journal of Biodiversity and Conservation 4(7), 294-303. Available online at http://www.academicjournals.org/ IJBC DOI: 10.5897/IJBC11.274.

Tefera, Y., Abebe, W., Teferi, B., 2016. Woody plants species diversity of home garden agroforestry in three agroecological zones of Dilla Zuria district, Gedeo Zone, Southern Ethiopia. Fauna Journal 2016, 3(3), 98-106.

Tefera, B.N., Kim, Y.D., 2019. Ethnobotanical study of medicinal plants used as antimalarial and repellent by Sidama people of Hawassa Zuria district, Southern Ethiopia. Journal of Complementary Medicine Research 10(1), 13-26.

Tamrat, S., 2010. Study of useful plants in and around Gette Ouduma (Traditional Gedeo homegardens) in kochere wereda, South Ethiopia; an ethnobotanical approach (Doctoral dissertation, M.Sc. Thesis, Addis Ababa University).

Udofia, S.I., Owoh, P.W., Ukpong, E.E., Ekpo, I.E., 2012. Assessment of plant species of socio-economic importance conserved in homegardens of Nsit-Ubium local government area of Akwa Ibom State, Nigeria. Nigerian Journal of Agriculture, Food and Environment 8(1), 99-108.

Wassihun, B., Asfaw, Z., Demissew, S., 2003. Ethnobotanical study of useful plants in Daniio gade (home-gardens) in Southern Ethiopia. Ethiopian journal of Biological Sciences 2(2), 119-141.

Wajtkowski, A., 1998. The theory and practice of agroforestry design. A comprehensive study of the teories, Concepts and Conventions that Underline the Successful Use of Agroforestry, Science Publishers, Inc., New York, NY, 
USA, 1998.

Zemede, A., 2001a. Home Gardens in Ethiopia: Some observations and genralizations, In: Watson, J.W., Eyzaguirre, P.B. (Eds.), contributions of home gardens to in situ conservation of plant genetic resources in farming systems (Proceedings of the Second International Home gardens Workshop) 17-19 July 2001, Witzenhausen, Federal Republic of Germany, 125-139.

Zemede, A., 2001b. The role of homegardens in the production and conservation of medicinal plants. In: Medhin, Z.,
Abebe, D. (Eds.), conservation and Sustainable use of Medicinal plants in Ethiopia, Proceedings of the National Workshop on Biodiversity Conservation and Sustainable Use of Medicinal Plants in Ethiopia. 28 April-1 May, 1998. Institute of Biodiversity Conservation and Research, Addis Ababa, Ethiopia, 76-91.

Zemede, A., Zerihun, W., 1997. Crop association of homegardens in Welayta and Gurage in Southern Ethiopia. SINET: Ethiop. Journal of Scientific 20(1), 73-90. 